\title{
The correlation of peer support and parental support with achievement motivation
}

\author{
Niko Reski ${ }^{1}$, A.Muri Yusuf ${ }^{2}$, Yanuar Kiram ${ }^{3}$ \\ ${ }^{1234}$ Universitas Negeri Padang, Padang - Indonesia, (nikoreski1@gmail.com)
}

\begin{abstract}
The background of this research was there are many of students who have low achievement motivation. Peer and parental support are two factor that allegedly influence it. Aims of this research to describe the correlation of peer and parental support with achievement motivation. This research used quantitative approach with descriptivecorrelational method. The population of this research consists 723 and samples 196 students. The instrument used questionnaire with likert scale model and the reliability test of peer support instrument at 0.864 , parental support at 0.903 and achievement motivation at 0,939 . The data were analyzed using multiple regression. The results shows that the peer and parental support, and the achievement motivation were in high category. There are correlation $(15.9 \%)$ of the peer and parental support with achievement motivation. The Implication of the research results can be used as an analysis of the needs of students in setting counseling service program at school.
\end{abstract}

Keywords: Peer support, parental support, achievement, motivation.

\section{Introduction}

The learning process was marked by a change in student behavior, through activities that can increase knowledge, experience, shaping attitudes, habits, and skills in school. The desired change in behavior of the learning process should be accompanied by a strong motivation of the student, so that students can be serious in learning, in order to reach the desired learning objectives can be achieved. Waruwu (2006) describes the role of motivation is very important in the success of the learning process, students have enough motivation to have a high interest to learn the subject matter, because the students will be encouraged to seek the necessary information and deepening of the subject matter of doing business.

Furthermore, likely achievement of success in learning when students have a motive for the achievement (Syofyan, 2012). The motive for achievement is also called the achievement motivation that characterizes the learning process of students in achievement. Achievement motivation is a desire to get things done by setting a standard of success to be achieved (Santrock, 2007). Achievement motivation moving the students to complete the task given to him very well, they set the standard to be achieved and sincere in doing the task. Achievement motivation made the students attempt prepared themselves to face any possible obstacles encountered to be able to obtain excellent results. 
Based on preliminary data obtained in SMK 2 Sungai Penuh discovered that not all students are able to achieve high performance seen from the results of student learning that has a low learning outcomes and the majority of students in the second semester has decreased compared to the first semester. According to interviews with guidance and counseling teachers at SMK Negeri 2 Sungai Penuh revealed that students have low achievement motivation, that seen from students are less eager to learn certain subjects, some students are less attention in explaining the course material in class, there are students who do not have a target value to be achieved, students do homework at school, students cheat on homework his friend, there are students who truant. Displayed behavior of students shows that students have low achievement motivation.

Furthermore, concerning achievement motivation revealed that student achievement motivation is at a low category (Adiningtyas, 2015). Alit research results (2003) revealed that describe student achievement motivation enough to be in a category. Furthermore, the research results Donal (2014) revealed that the general student achievement motivation in middle category. Research illustrates that the student has not had a high achievement motivation in school. Students who do not have high achievement motivation for achievement lacked a seriousness and responsibility in learning and tend to avoid competition in achieving learning in school.

According Santrock (2007) that the relationship between students and parents, peers, teachers, mentors, and others can affect their achievement and motivation. In accordance with the opinion of McClelland (1987) describes one of the factors that affect achievement motivation is students of environmental conditions, such as the support given by parents and peers. Student interaction with the environment that has close emotionally, like parents and peers will be very influential on the development of students. Students who earn positive reinforcement and support from their parents and peers as well as in the struggle for achievement want to accomplish will have a better achievement motivation of the students who lack support.

Based on the results of research conducted by Elmirawati (2013) show that parental support positive effect on student motivation in learning. The consistent support from parents is crucial in maintaining the confidence and desire of students to learn. Parents who provide support for their children, such as giving attention to the problems faced by students mainly study the problems makes the students are motivated to study harder in achieving a better or higher. Furthermore, the results of research conducted by Saragi (2016) regarding the support of parents showed that support parents have a significant impact on student motivation. Parents who are concerned about the development and progress of their children's education will meet to provide the best for their children in order to support his son's achievement.

In addition to the support of parents, achievement motivation is also influenced by peer support (Santrock, 2007). Peers are people who have the maturity, age, and perspectives about the same as students. Students can learn social roles and standards relating to the work and achievements, influence each other, including the influence of achievement motivation of the students. The support given by peers gives a feeling of self-worth in the students, help students form positive habits, encourage students to try new things, and assist in achieving the diingikannya.

Based on the above, achievement motivation plays an important role in the learning process at school. Student achievement motivation is influenced by environmental conditions which provide support to students. the most influential environment on students as a teenager is a peer environment and parents. This is the basis of research carried out to reveal the peer support relationship with achievement motivation.

The purpose of this study to describe: (1) peer support at SMK Negeri 2 Sungai Penuh, (2) parental support in SMK Negeri 2 Sungai Penuh, (3) achievement motivation in SMK Negeri 2 Sungai Penuh, (4) the correlation of peer support and achievement motivation in SMK Negeri Sungai Penuh, (5) the correlation of parental support and achievement motivation in SMK Negeri 2 Sungai Penuh, 
(6) the correlation of peer support and parental support with achievement motivation in SMK Negeri 2 Sungai Penuh.

\section{Method}

This study uses a quantitative approach with descriptive correlational. The study population were students of class X and XI in SMK Negeri 2 Sungai Penuh 723 students. Considering the large amount of the sample, it is necessary to use sampling with proportional random sampling, in order to obtain samples of 258 students. The instrument used questionnaire with scale likert model and five alternative answers. Furthermore, an analysis to determine the relationship of independent variables on the dependent variable with simple regression and multiple regression.

\section{Results and Discussion}

The data in this study include peer support, parental support, and achievement motivation.

1. Peer Support

Table 1. Frequency and Percentage Distribution Peer Support

\begin{tabular}{|c|c|c|c|}
\hline Interval Scores & Category & Frequency & Percentage (\%) \\
\hline$\geq 135$ & Very High & 22 & $8: 53$ \\
\hline 109-134 & High & 229 & 88.76 \\
\hline $83-108$ & Medium & 7 & 2.71 \\
\hline $57-82$ & Low & 0 & 0 \\
\hline$\leq 56$ & Very Low & 0 & 0 \\
\hline \multicolumn{2}{|c|}{ Total } & 258 & 100 \\
\hline
\end{tabular}

Table 1 shows that the students of SMK Negeri 2 Sungai Penuh have high peer support. These results illustrate that the peer support in SMK Negeri 2 Sungai Penuh has been good, but there are students who have a peer support medium, and high. The score variations need to be taken to ensure all students can improve and maintain peer support.

2. Parental Support

Table 2. Frequency and Percentage Distribution of Parental Support

\begin{tabular}{cccc}
\hline Interval Scores & Category & Frequency & Percentage (\%) \\
$\geq 169$ & Very High & 27 & $10: 46$ \\
$137-168$ & High & 230 & 89.15 \\
$105-136$ & Medium & 1 & $0: 39$ \\
$73-104$ & Low & 0 & 0 \\
$\leq 72$ & & 0 & 0 \\
& very Low & 258 & 100 \\
\hline
\end{tabular}

Table 2 shows that students of SMK Negeri 2 Sungai Penuh has a high parental support. These results illustrate that the parental support in SMK Negeri 2 Sungai Penuh has been good, but there are variations scores obtained by the parental support of students in the medium category, and very high. The score variations need to be taken to ensure all students can improve and maintain the parental support.

3. Achievement Motivation 
Table 3. Frequency and Percentage Distribution of Achievement Motivation

\begin{tabular}{|c|c|c|c|}
\hline Interval Scores & Category & Frequency & Percentage (\%) \\
\hline$\geq 203$ & Very High & 12 & 4.65 \\
\hline $165-202$ & High & 159 & 61.63 \\
\hline $127-164$ & Medium & 75 & 07.29 \\
\hline $89-126$ & Low & 12 & 4.65 \\
\hline$\leq 88$ & Very Low & 0 & 0 \\
\hline \multicolumn{2}{|c|}{ Total } & 258 & 100 \\
\hline
\end{tabular}

Table 3 shows that students of SMK Negeri 2 Sungai Penuh have high achievement motivation. These results illustrate that the students already have a good achievement motivation, but still there are variations in achievement motivation score dipeoleh students in the category of low, medium, and high. The score variations need to be taken to ensure all students can improve achievement motivation is high or even very high.

Test requirements analysis undertaken in this study is a test for normality, linearity test, and a test multicollinearity.

1. Normality Test

Normality test is done using the Kolmogorov Smirnov showed that the value Asymp. Sig. variable of 0.473 peer support, the support of parents of 0,556 , and achievement motivation of 0.358 greater than 0.005 . That is, all normally distributed variables.

2. Linearity test

Linearity test results showed that peer support variable data and achievement motivation is linear with the Sig.0.000 0:05. Parent support variable data and achievement motivation is also linear with Sig.0.000 0:05.

3. Test Multicolinearity

Multikolinearity test results showed that there were multicollinearity between the variables of peer support and parental support, the value VIF peer support of $1.002<10$, and VIF parental support $1,002<10$.

The Correlation of Peer Support and Parental Support with Achievement Motivation.

1. The Correlation of Peer Support with Achievement Motivation analysis results peer support with achievement motivation correlation can be seen in Table 4 .

Table 4. Results of Simple Regression Analysis and Significance X1 to Y

\begin{tabular}{ccc}
\hline Variable & $\mathrm{R}$ & $\mathrm{R}^{2}$ \\
$\mathrm{X}_{1}-\mathrm{Y}$ & 0.372 & 0.107 \\
\hline
\end{tabular}

Table 4 shows that the $\mathrm{R}$ value of 0.372 , which shows the regression coefficient between peer support and achievement motivation. $\mathrm{R}^{2}$ of 0.107 which showed that peer support had a significant correlation with achievement motivation. It also means the peer support influence achievement motivation at $10.7 \%$, the rest is influenced by other factors.

2. The Correlation of Parental Support with Achievement Motivation

The results of the analysis of parental support with achievement motivation correlation can be seen in Table 5.

Table 5. Regression Analysis Simple and Test Significance X2 to Y

\begin{tabular}{ccc}
\hline Variable & $\mathrm{R}$ & $R$ Square \\
$\mathrm{X}_{2} \mathrm{Y}$ & 0.243 & 0.059 \\
\hline
\end{tabular}


In Table 5 shows that the $\mathrm{R}$ value of 0.234 , which shows the regression coefficients between parental support and achievement motivation. $\mathrm{R}^{2}$ of 0.059 which indicates that the parental support has a significant relationship with achievement motivation. It also means the parental support affects the motivation of achievement at $10.7 \%$, the rest is influenced by other factors.

3. The Correlation of Peer Support and Parental Support with Achievement Motivation

Analysis results the correlation of peer support and the parental support and achievement motivation can be seen in Table 6 .

Table 6. Results of Analysis and Significance Regression Peer Support and Parental

Support to Achievement Motivation

$\begin{array}{lcc}\text { Variable } & \mathrm{R} & \mathrm{R}^{2} \\ \mathrm{X}_{1} \mathrm{X}_{2}-\mathrm{Y} & 0.398 & 0.159\end{array}$

Table 6 shows that the $\mathrm{R}$ value of 0.398 which indicates regression coefficient peer support and parental support with achievement motivation. $\mathrm{R}^{2}$ of 0.159 that show peer support and the parental support has a significant with achievement motivation. It also means the peer support and parental support affects the motivation of achievement at $10.7 \%$, the rest is influenced by other factors.

\section{Conclusions}

Based on the results of testing that has been done that there is a significant correlation between peer support, parental support with motivation berpretasi. In the following sections will explain the discussion for each variable in the study.

\section{Peer Support}

Results of data analysis showed that the overall average peer support students are in the high category. This means that peer support is good. Based on the achievement of each indicator is known that seven indicators are on a high, namely: giving attention, giving empathy, aid equipment, giving instructions, giving advice, giving positive expression, giving a boost expression. However, there are two indicators of achievement in middle category, namely: the provision of assistance in the form of time, and the provision of assistance in the form of time.

Students who have high peer support will assist students in developing themselves into a better direction, making the students feel valued, more confident, and gained a boost to perform better sesuatuu. Berndt (in Santrock, 2007) reveals that adolescents have nearly the same success orientation with peers. Peers who have success in an academic orientation will affect the students. Students will be motivated to have the same performance with their peers. They spend much time together, so they would often exchange opinions about various things, including in terms of achievement.

\section{Parental Support}

Based on the results of data analysis reveal that the average overall parental support at the high category. Achievement in each of the indicators is known that all the indicators are at a high category. this means that the parental support is good.

Support parents who are at a high category will take effect and be required to improve student achievement motivation. High parental support will give you confidence in students, a sense of security and comfort for students to struggle to achieve student achievement. John (2011) explained that the support of parents in the member encouragement and motivation to build self-esteem of students, fostering high morale, and makes students want to do activities to learn well and controlled. Therefore, the support of parents on the development of student achievement embodied in the efforts made by parents to provide the best for their children, whether it is providing support morally, the 
facilities good learning, providing education expenses, and other needs that support students to achieve the expected achievement

\section{Achievement Motivation}

Results of data analysis showed that the overall average achievement motivation of students at the high category. Based on the achievement of each indicator is known that there are two indicators that are in the medium category, namely: to evaluate the results and look for information to find new ways of completing the task. That is, although the achievement motivation of students already in the high category, but there are other indicators that are still in the moderate category and need to be followed up so that all the indicators can be improved menajdi high or even very high.

Based on the initial information to guidance and counseling teachers at SMK Negeri 2 Sungai Penuh, it is known that students tend to have low achievement motivation. However, based on the results of the research that has been done obtained data illustrate that students have high achievement motivation. This happens because at the time of the initial information provided by the guidance and counseling teachers and from observations of the researchers is to see from some students only. Meanwhile, a study conducted to determine the overall student achievement motivation with a sample of 258 students.

Winkel (2007) describes the achievement motivation is manifested as the driving force for students to be serious in learning with the aim of achieving a high performance and for the sake of self-esteem. High achievement motivation in students will have an effect on the efforts of students to realize that to achieve student achievement in the learning process.

High achievement motivation is important to be maintained and developed in students. Shekhar \& Devi (2012: 105)"Achievement motivation is considered a prerequisite for success in academic settings". This means that achievement motivation is regarded as a prerequisite for success in the academic field. High achievement motivation will tend to bring students more successful academically than students who still have high levels of achievement motivation was especially low.

\section{The Correlation of Peer Support with Achievement Motivation}

Results showed that there was a significant correlation between peer support and achievement motivation. These results indicate that the peer support with achievement motivation of $10.7 \%$. That is, peer support is one of the factors that influence achievement motivation.

The results of the study, reinforced by Santrock theory (2003) that the support of peers more influence on the level of confidence students gain an appreciation of himself and feedback regarding the ability/competence themselves. Students spend more time with peers by doing activities together, so that they can exchange opinions, reward, encouragement and attention. The support given by peers would affect confidence in the students' achievement. They become more confident in their capabilities and try to fight for achievement in school.

In line with the research results Altermat \& Broady (in Iksan, 2013), which explains that peers have a very important role in providing direct support that interaction to build a high achievement motivation. Peer support will affect the motivation of underachievement that can be seen from the behavior of students become more enthusiastic in learning, students came to believe that his friend was able to help him finish learning difficulties encountered, the students are willing to take the time to study together with his friend, and students prepared various information with friends -her friend.

Based on the above, it is understood that there is a relationship between peer support student achievement motivation. That is, high student achievement motivation can be seen from the support of peers. Therefore, to develop and improve student achievement motivation should be developed also peer support. 


\section{The Correlation of Parental Support with Achievement Motivation}

Results showed that there was a significant correlation of parental support and motivation berprestasi. This Result shows is correlation of parental support with achievement motivation amounted to $5.9 \%$. That is, the support of parents is one of the factors that influence achievement motivation.

The results of this study illustrate that the higher the support of parents, the higher the student achievement motivation. This is consistent opinion of John (2011) that support parents in giving encouragement and motivation to build self-esteem of students, fostering high morale, and makes students want to do activities to learn well and controlled.

A good parent support needed by students to develop confidence in students to do something better, arouse the desire of students to try as much as possible in the fight for something you want. Support parents may be giving emotional support, instrumental, information, and respect for the students, so that students are motivated to achieve excellence in learning.

Based on the above, illustrates important for students to gain the support of parents in improving student achievement motivation in school.

5. The Correlation of Peer Support and Parental Support with Achievement Motivation

Results showed that there was a significant correlation of peer support and parental support with achievement motivation for $15.9 \%$. These results explain that the higher the peer support and parental support can be increas achievement motivation.

Students who have peer support and parental support has a sense of worth, confidence in the capabilities, and seriously do something to completion, and oriented to get the best results. So that students who received peer support and parental support is able to achieve in school. According to Rosenfeld (in Ahmed 2010) explains that when students have high support from peers, parents, and teachers, the students will have a better performance than those without support. Students who get good support will increase students' motivation to strive to realize the desired performance in school. Support positive about the attention, respect, and support from peers and parents to students to make students motivated to achieve optimal performance.

Research results revealed that peer support is more influential on students to improve achievement motivation than the support of parents. It can be understood that the student as a teenager wants to be accepted in a peer environment, they will spend more time together, exchange ideas, that would affect their peers on the attitudes, habits, interests, appearance that they show a greater than parents ( Hurlock, 2007).

Students have a wide social environment that is formed from several smaller social environment, the family and peers, to support it in the face of the demands of life and achieve the goal of his life (Vaux in Azizi, 2013). Peers as part of the students' social environment that can provide positive or negative influence, including in forming social patterns among them. Teens have a tendency to divert their feelings as a substitute parent, ie peers, where peers serve as one source of information about a lot of things acquired teens outside the family.

Results of research conducted by Nickerson \& Nagle (2005) revealed that in adolescence communication and trust of parents is reduced and shifted toward peers to meet the need for attachment. Parents are lots provide oversight of student behavior, this is less favored by students and they tend to look for a place where students can not be over-policed. Peer environment provide a space for students to do something to their liking. They are free to do anything, so that the negative behavior of the same age can not be avoided.

Parents as the person most responsible for the development of students need to be closer to his son to give more space for students to explore students. However, parents need to direct the student to 
provide an understanding of the effects that from something that is done by the students. thus, students can avoid the various behaviors and negative consequence of something he did.

Based on the above, it can be concluded that peer support and the support of parents will affect student achievement motivation. The results of these studies need to be followed to continue to develop and improve student achievement motivation, so that students are capable of achievement.

The conclusion can be stated as follows: (1) In general, peer support at SMK Negeri 2 Sungai Penuh at the high category, (2) In general, parental support in SMK 2 Sungai Penuh at the high category, (3) In general, achievement motivation of students in SMK 2 Sungai Penuh at the high category, (4) There are significant correlation of peer support with achievement motivation. That is, the higher the peer support, the higher the student achievement motivation, (5) There are significant correlation of parental support with achievement motivation. That is, the higher the support of parents, the higher the student achievement motivation, (6) There are significant correlation of peer support and parental support together with achievement motivation. That is, the higher the peer support and the parental support, the higher the achievement motivation.

\section{Acknowledgments}

Thanks for Prof. Dr. A. Muri Yusuf, M.Pd. and Prof. Dr. Phil. Yanuar Kiram., as the Supervisor were always patient and sincere take the time to provide guidance, direction, knowledge, and advice and motivation to researchers to perfection this research. Prof. Dr. Mudjiran., MS, Kons., Dr. Syahniar, M.Pd., Kons., and Dr. Afdal, M.Pd., Kons., as contributors and expert judgment that have provided input, guidance, advice, and continues to provide support for the improvement and perfection of this research. Thanks to all of lecturers and staffs in master Guidance and Counseling, Fakultas Ilmu Pendidikan, Universitas Negeri Padang, and all of teachers, staffs, and students in SMK Negeri 2 Sungai Penuh for knowledge, help, and support during the completion of this research.

Spesial thank to my parents to giving support in the completion of this research, and all of student in master Guidance and Counseling, Fakultas Ilmu Pendidikan, Universitas Negeri Padang which continues to provide motivation and valuable input for the sake of the completion of this research.

\section{References}

Adiningtiyas, S. W. (2015). Efektivitas Layanan Informasi dengan Media untuk Meningkatkan Motivasi Berprestasi Siswa. Thesis. Padang: Universitas Negeri Padang.

Ahmed, W., Minnaert, A., Werf, G. V. D., \& Kuyper, H. (2010). Perceived Social Support and Early Adolescents' Achievement: The mediational roles of motivational beliefs and emotions". Journal Youth Adolescence, 2(1):36-46.

Alit, D. M. (2007). Kontribusi Faktor Lingkungan Sekolah, Lingkungan Keluarga dan Motivasi Berprestasi terhadap Nilai Modern Siswa Sekolah Lanjutan Tingkat Pertama (SLTP) di Kabupaten Gianyar, Bali. Jurnal Penelitian dan Evaluasi, 6(1):13-39.

Azizi, Y. (2013). The Study of the Relationship among Emotional Intelligence, Peer Social Support, and Family Social Support and GPA among Iranian High School Students. Journal of natural and Social Sciences, 2(2):650-658

Donal. (2014). “Kontribusi Konsep Diri dan Motivasi Berprestasi terhadap Arah Perencanaan Karier Siswa (Studi Pada SMAN 2 Kampar Kiri)". Thesis. Padang: Universitas Negeri Padang.

Elmirawati. (2013). Hubungan antara Aspirasi Siswa dan Dukungan Orang Tua dengan Motivasi Belajar serta Implikasinya terhadap Bimbingan dan Konseling. Konselor, 2(1):107-113

Graha, C. (2007). Keberhasilan Anak Tergantung Orangtua. Jakarta: Gramedia.

Hamzah B. U. (2011). Teori Motivasi dan Pengukurannya. Jakarta: Bumi Aksara. 
Iksan, M. (2013) Dukungan Sosial pada Prestasi dan Faktor Penyebab Kegagalan Siswa SMP dan SMA. Jurnal Psikoislamika, 10(1):117-123

Jahja, Y. (2011). Psikologi Perkembangan. Jakarta: Kencana Prenada Media.

McClelland, D. C. (1987). Human Motivation. Glenview: Scott Foresman.

Nickerson, A.B. \& Nagle, R.J. (2007). Parent and Peer Attachment in Late Childhood and Early Adolescence. Journal of Early Adolescence, 25(2):223-249.

Saragi, M. P. D. (2016). Kontribusi konsep diri dan dukungan orang tua terhadap motivasi belajar siswa serta implikasinya dalam pelayanan bimbingan dan konseling. Thesis. Padang: Universitas Negeri Padang.

Santrock, J. W. (2007). Psikologi pendidikan (2 ${ }^{\text {nd }}$ ed.). Terjemahan oleh Tri Wibowo B.S. Jakarta: Kencana

Shekhar, C., \& Devi, R. (2012). Achievement Motivation Across Gender and Different Academic Majors. Journal Education and Development Psychology, 2(2): 105-109.

Syofyan. 2012. Psikologi Pendidikan. Bandung: Alfabeta

Waruwu, F.E. (2007)."Belajar dan Motivasi: Bagaimana meningkatkan motivasi interna”. Jurnal Provitae, 2(2): 21-25.

Winkel, W. S. (2007). Psikologi Pendidikan dan Evaluasi Belajar. Jakarta: Gramedia. 